\title{
Cloning of Genes Determining the Production of Vero Cytotoxin by Escherichia coli
}

\author{
By G. A. WillshaW, ${ }^{*}$ H. R. SMITH, S. M. SCOTLAND ANd B. ROWE \\ Division of Enteric Pathogens, Central Public Health Laboratory, Colindale Avenue, \\ London NW9 5HT, UK
}

(Received 11 June 1985; revised 13 July 1985)

Sequences encoding the production of a cytotoxin (VT) active on Vero cells were cloned in Escherichia coli K12 from a VT-determining phage that originated in $E$. coli strain $\mathrm{H} 19$ of serotype $\mathrm{O} 26$. H11. Subcloning resulted in the identification of a $2.5 \mathrm{~kb}$ fragment that still coded for VT production. Mutagenesis with transposon Tn 1000 was used to map VT sequences and a $0.75 \mathrm{~kb}$ probe was developed. In colony hybridization tests with strains isolated from patients with haemolytic uraemic syndrome or diarrhoea, this probe derived from the H19 VT genes detected only some of the $\mathrm{VT}^{+}$strains belonging to serogroup O157. A $\mathrm{VT}^{+}$strain, E32511, serotype $0157 . \mathrm{H}^{-}$, which was negative in colony hybridization was the source of another VTdetermining phage from which VT sequences were cloned. Southern hybridization of the VT genes from E32511 with the $\mathrm{H} 19$ probe was negative under stringent conditions but there was weak homology under conditions of low stringency. These results indicate that there are differences in the VT genes of pathogenic $E$. coli.

\section{INTRODUCTION}

Certain strains of Escherichia coli that cause diarrhoea have been shown to produce a heatlabile cytotoxin active on Vero cells (Konowalchuk et al., 1977; Scotland et al., 1980a). The Vero cytotoxin (VT) was distinguishable from the heat-labile and heat-stable enterotoxins of $E$. coli. It has been proposed that VT is probably identical to Shiga toxin, the cytotoxin produced by strains of Shigella dysenteriae type 1 (O'Brien et al., 1982, 1983a,b). Production of VT in E. coli has been associated with certain strains belonging to enteropathogenic serogroups that cause diarrhoea in infants and in which production of heat-labile or heat-stable enterotoxins has not been demonstrated. The occurrence of VT production in these strains is most common in serogroup $\mathrm{O} 26$ but $\mathrm{VT}^{+}$strains belonging to other serogroups have been reported (Konowalchuk et al., 1977; Wade et al., 1979; Scotland et al., 1980a,b).

Studies in Canada and the USA have demonstrated VT production by $E$. coli strains of serotype O157. H7 associated with cases of haemorrhagic colitis (Johnson et al., 1983; O'Brien et $a l ., 1983 b$ ) and by strains of serogroups $\mathrm{O} 26, \mathrm{O} 111, \mathrm{O} 113$ and $\mathrm{O} 157$ isolated from patients suffering from haemolytic uraemic syndrome (HUS) (Karmali et al., 1983a, b). The latter syndrome, principally seen in young children, is frequently associated with prodromal bloody diarrhoea. Several cases of HUS were reported in England and Wales during 1983 and VTproducing $E$. coli O157.H7 were isolated from some cases (Gulley, 1984; Smith et al., 1984).

VT-producing $E$. coli of serogroups 0138,0139 and $\mathrm{O} 141$ have also been associated with enteric infections in pigs, particularly with post-weaning diarrhoea and oedema disease (Konowalchuk et al., 1977; Kashiwazaki et al., 1980, 1981; Williams Smith et al., 1983). However, evidence from all these workers indicated that the VT from porcine strains was antigenically distinct from that produced by human $E$. coli. 
Studies on the genetics of VT production showed that the property could be transferred from a strain of E. coli O26.H11 (strain H19) to E. coli K12 (Williams Smith \& Linggood, 1971; Scotland et al., 1980a). However, there was no evidence for plasmid involvement, and subsequently the genes encoding VT in $\mathrm{H} 19$ were shown to be on a bacteriophage (Scotland $e t$ al., 1983; Williams Smith et al., 1983). The latter authors also identified VT-carrying phages in a second $\mathrm{O} 26$ strain and in two strains of serogroup O128. Phages that determine VT production have also been detected in two $E$. coli 0157 strains isolated from cases of HUS and bloody diarrhoea in Britain (Smith et al., 1984), and production of Shiga-like toxin has been shown to be phage mediated in a strain of $\mathrm{O} 157 . \mathrm{H} 7$ isolated during an outbreak of haemorrhagic colitis (O'Brien et al., 1984). In contrast to this situation in human strains, a bacteriophage has not been implicated in the mediation of VT production in a porcine E. coli strain (Williams Smith et al., 1983).

Preliminary experiments showed that a VT-determining phage from strain $\mathrm{H} 19$, purified from $E$. coli $\mathrm{K} 12$, contained DNA with a molecular weight of approximately $30 \times 10^{6}$ (Scotland et al., 1983). The present study was undertaken to extend the physical characterization of the phage genome and, particularly, to locate the genes determining production of VT by molecular cloning and transposon mutagenesis. This information was then applied to the development of specific genetic probes for the detection of $\mathrm{VT}^{+} E$. coli associated with HUS and other diseases in which VT production has been implicated.

\section{METHODS}

Strains, plasmids and bacteriophages. E. coli K12 AB1157 (Bachmann, 1972) was used for propagation of the bacteriophages coding for VT production. The strains used in the mating and cloning experiments were AB1157, HB101 (Maniatis et al., 1982) and 14R519 (E. coli K12 Lac- Pro- Trp- His- Nal'). Wild-type E. coli strains used in hybridization experiments are listed in Table 1 . The vectors used for cloning DNA fragments were pBR322, which determines ampicillin and tetracycline resistance (ApTc), pACYC184, chloramphenicol and tetracycline resistance $(\mathrm{CmTc})$, and $\mathrm{pACYC177}$, ampicillin and kanamycin resistance $(\mathrm{ApKm})$. The plasmid $\mathrm{F}^{\prime}$ pro lac:: $\mathrm{Tn} 5$ (Jorgensen et al., 1979) was used in transposon mutagenesis experiments. Bacteriophages coding for VT production were described previously (Scotland et al., 1983; Smith et al., 1984); the VT phages originated in E. coli strain H19, serotype O26. H11 and strain E32511, serotype O157. $\mathrm{H}^{-}$.

Tests for VT production. Large numbers of colonies were screened for VT production by a rapid method adapted from that used to detect heat-labile enterotoxin. Monolayers of Vero cells grown in medium 199 with Earles salts were prepared in microtitre tissue culture plates. Each bacterial colony was grown in $0.5 \mathrm{ml}$ syncase/glucose medium without shaking at $37^{\circ} \mathrm{C}$ for $24 \mathrm{~h}$. A sample of culture $(50 \mu \mathrm{l})$ was added to a monolayer of Vero cells and after $10 \mathrm{~min}$ the culture was removed and the monolayer washed with PBS $(0 \cdot 15 \mathrm{M}-\mathrm{NaCl}, 0 \cdot 15 \mathrm{M}$-sodium phosphate, $\mathrm{pH} 7 \cdot 2)$. Growth medium containing gentamicin $\left(40 \mu \mathrm{g} \mathrm{ml}^{-1}\right)$, streptomycin $\left(100 \mu \mathrm{g} \mathrm{ml}^{-1}\right)$ and penicillin $\left(100 \mathrm{IU} \mathrm{ml}^{-1}\right)$ was added and the plate resealed and incubated at $37^{\circ} \mathrm{C}$ for $3-4 \mathrm{~d}$. After fixing with methanol and staining with Giemsa stain, the monolayer was examined for any cytotoxic effect.

VT production was confirmed using sterile culture supernatants by the method described previously (Scotland $e t$ al., 1980a).

Propagation and preparation of phages. VT phages from strains $\mathrm{H} 19$ and E32511 were propagated on the indicator strain $\mathrm{AB} 1157$ grown in $\mathrm{L}$ broth containing $5 \mathrm{mM}-\mathrm{MgSO}_{4}$. Phage was precipitated with polyethylene glycol $6000(10 \%, w / v)$ and the concentrated phage was purified by banding in a caesium chloride step gradient. The resulting phage stock contained between $10^{11}$ and $10^{12}$ p.f.u. $\mathrm{mi}^{-1}$. Phage DNA was extracted with phenol and dialysed against $10 \mathrm{~mm}$-Tris/1 mM-EDTA, pH 8.

Preparation of plasmid DNA. Purified DNA of plasmid vectors and recombinant plasmids was prepared from $500 \mathrm{ml}$ cultures by polyethylene glycol precipitation and caesium chloride density gradient centrifugation (Humphreys et al., 1975). For rapid screening, DNA of recombinant plasmids was extracted by the method of Birnboim \& Doly (1979).

Restriction endonuclease treatment and recombinant DNA techniques. Samples of phage or plasmid DNA were digested with restriction enzyme under the conditions suggested by the manufacturers (BRL or Boehringer). Where appropriate, digested source and vector DNAs were mixed and incubated with T4 DNA ligase at $10-15^{\circ} \mathrm{C}$ overnight. The mixtures were used to transform E. coli K12 (Dagert \& Ehrlich, 1979). Transformants were selected according to the drug resistance markers of the vector plasmid (see above) and those carrying hybrid plasmids were identified by insertional inactivation of these markers.

Isolation of mutants no longer coding for VT production. Transposon mutagenesis was used to isolate plasmid mutants that no longer coded for VT production. The F prime factor $\mathrm{F}^{\prime}$ pro lac: $: \mathrm{Tn} 5$ carries the $\gamma \delta$ sequence 
designated Tn 1000 (Guyer, 1978). This plasmid was transferred into E. coli K12 carrying NTP703, a recombinant plasmid coding for VT production (see Results). Strains carrying NTP703, which determines tetracycline resistance, and $\mathrm{F}^{\prime}$ pro lac: : $\mathrm{Tn} 5$, which codes for kanamycin resistance, were mated for $1 \mathrm{~h}$ at $37^{\circ} \mathrm{C}$ with $\mathrm{AB} 1157$ with selection for tetracycline resistance $\left(10 \mu \mathrm{g} \mathrm{ml}^{-1}\right)$. Transconjugants were examined for plasmid DNA and the molecular weights compared with that of NTP703. Strains carrying NTP703 with Tn1000 insertions were tested for VT production. Plasmid DNA preparations from these strains were used to transform E. coli $14 \mathrm{R} 519$ and transformant colonies were examined by agarose gel electrophoresis to check for the presence of NTP703 : : Tn 1000 only.

Agarose gel electrophoresis. Initial examination of plasmid DNA was on vertical $0.6 \%(\mathrm{w} / \mathrm{v})$ agarose gels run in TB buffer containing $89 \mathrm{~mm}$-Tris base, $89 \mathrm{~mm}$-boric acid and $2.5 \mathrm{~mm}$-EDTA (Willshaw et al., 1979). The products of restriction enzyme digestion were separated on vertical $1 \%(\mathrm{w} / \mathrm{v})$ agarose gels run for $16 \mathrm{~h}$ in TA buffer (pH 7.9) containing $40 \mathrm{~mm}$-Tris base, $5 \mathrm{~mm}$-sodium acetate and $1 \mathrm{~mm}$-EDTA. Preparative electrophoresis to isolate specific DNA fragments for radioactive labelling was done similarly using wide slots to accommodate large sample volumes. For the analysis of DNA fragments smaller than $750 \mathrm{bp}$, separation was on gels containing $3 \%$ (w/v) acrylamide and $0.5 \%(w / v)$ agarose run in TB buffer at $70 \mathrm{~V}$ for 3 to $4 \mathrm{~h}$ (Peacock \& Dingman, 1968). Standards for the determination of molecular weights of restriction fragments were either $\lambda$ phage DNA treated with HindIII and EcoRI (Southern, 1979) or DNA of pBR322 digested with Hinf (Maniatis et al., 1982), depending on the size range of fragments separated. Transfer of DNA fragments from gels to nitrocellulose (Schleicher \& Schüll BA85) was by the method of Southern (1975).

Preparation of filters for colony hybridization. Broth cultures of strains were spotted on BA85 nitrocellulose filter discs (diam. $82 \mathrm{~mm}$ ). The filters were incubated overnight on MacConkey agar plates at $37^{\circ} \mathrm{C}$ and then prepared for hybridization by the method of Maniatis et al. (1982).

DNA hybridization. Restriction fragments for use as hybridization probes were excized under long wavelength UV from preparative agarose gels and recovered by electroelution in TA buffer. The DNA solution was extracted once with phenol (equilibrated with TE buffer containing $0.01 \mathrm{~m}$-Tris $\mathrm{HCl}, \mathrm{pH} 8$, and $1 \mathrm{mM}-\mathrm{EDTA}$ ) and several times with $n$-butanol before precipitation with ethanol. DNA eluted from several gels was pooled and dissolved in 30-50 $\mu \mathrm{l}$ TE buffer. DNA fragments were radioactively labelled by nick translation (Maniatis et al., 1982) using deoxyadenosine $5^{\prime}-\alpha-\left[{ }^{35}\right.$ S $]$ thiotriphosphate (New England Nuclear).

The conditions for hybridization of denatured radio-labelled probe to DNA immobilized on nitrocellulose filters were as follows.

(1) Hybridization at 'high' stringency was carried out in a mixture containing $50 \%(\mathrm{v} / \mathrm{v})$ formamide, $5 \times \mathrm{SSPE}$ ( $1 \times \mathrm{SSPE}, \mathrm{pH} 7 \cdot 4$, is $0.18 \mathrm{~mm}-\mathrm{NaCl}, 10 \mathrm{mM}-\mathrm{NaH}_{2} \mathrm{PO}_{4}$ and $1 \mathrm{~mm}-\mathrm{EDTA}$ ), $0.1 \%$ each of Ficoll (MW 400000), polyvinylpyrrolidone, bovine serum albumin and SDS, $0.01 \mathrm{M}$-dithiothreitol and $100 \mu \mathrm{g}$ denatured salmon sperm DNA ml ${ }^{-1}$. After washing for $2 \mathrm{~h}$ in $50 \mathrm{~mm}-\mathrm{Tris} / \mathrm{HCl}(\mathrm{pH} 8.0)$ containing $1 \mathrm{M}-\mathrm{NaCl}, 1 \mathrm{~mm}-\mathrm{EDTA}$ and $0 \cdot 1 \%$ SDS, nitrocellulose filters were incubated for $4 \mathrm{~h}$ in hybridization solution without labelled probe. They were then transferred to 20-25 ml fresh hybridization solution containing $10^{6}$ to $10^{7}$ c.p.m. heat-denatured probe DNA and incubated for $16 \mathrm{~h}$. All stages were at $42^{\circ} \mathrm{C}$. Washing of the filters was in (i) four changes ( $10 \mathrm{~min}$ each) of $2 \times \mathrm{SSC}$ containing $0.1 \%$ SDS at room temperature $(1 \times \mathrm{SSC}$ is $0.15 \mathrm{M}-\mathrm{NaCl}$ and $0.015 \mathrm{M}$-trisodium citrate, $\mathrm{pH} 7.0) ;$ (ii) $1 \times$ $\mathrm{SSC} / 0.1 \% \mathrm{SDS}$ at $68^{\circ} \mathrm{C}$ for $2 \mathrm{~h}$; (iii) $0.2 \times \mathrm{SSC} / 0.1 \% \mathrm{SDS}$ for $1 \mathrm{~h}$ at $68^{\circ} \mathrm{C}$. Filters were allowed to dry at room temperature and exposed to Kodak XAR X-ray film at $-70^{\circ} \mathrm{C}$ for times varying between 7 and $40 \mathrm{~h}$.

(2) Hybridization at lower stringency was carried out as described above except that the hybridization mixture contained $25 \%(\mathrm{v} / \mathrm{v})$ formamide and the temperature was $37^{\circ} \mathrm{C}$ (Moseley et al., 1983). Washing was in $5 \times$ $\mathrm{SSC} / 0 \cdot 1 \% \mathrm{SDS}$ for $45 \mathrm{~min}$ at $54^{\circ} \mathrm{C}$ followed by $30 \mathrm{~s}$ at room temperature in $2 \times \mathrm{SSC}$.

\section{RESULTS AND DISCUSSION}

\section{Cloning of phage DNA encoding VT and location of $V T$ sequences}

Unsuccessful attempts were made to clone VT sequences from complete digests of phage $\mathrm{H} 19$ ( $\phi \mathrm{H} 19)$ using the restriction enzymes HindIII, BamHI, PstI, SalI, XhoI, ClaI, EcoRI, SmaI and $B g l$ II. However, a recombinant plasmid encoding VT was obtained from a digest of $\phi$ H19 DNA with HindIII plus $X h o$ I that had been ligated with similarly cleaved pACYC177. This plasmid, NTP702 (Fig. 1 $a$ ), had a molecular size of about $12 \mathrm{~kb}$ and contained a HindIII fragment of $3.2 \mathrm{~kb}$ and a XhoI-HindIII fragment of $5.1 \mathrm{~kb}$.

To determine the approximate position of VT sequences, PstI fragments of NTP702 were ligated with PstI-cleaved pBR322. In two of three $\mathrm{VT}^{+}$transformants obtained (20 tested) a $10.8 \mathrm{~kb}$ hybrid plasmid was present, the structure of which is shown in Fig. 1 (b) (NTP703). The plasmid contained PstI fragments of $6.3 \mathrm{~kb}$ and $0.45 \mathrm{~kb}$ from NTP702; the latter fragment did not contain a BamHI site, indicating that in forming NTP703 the PstI fragment of NTP702 


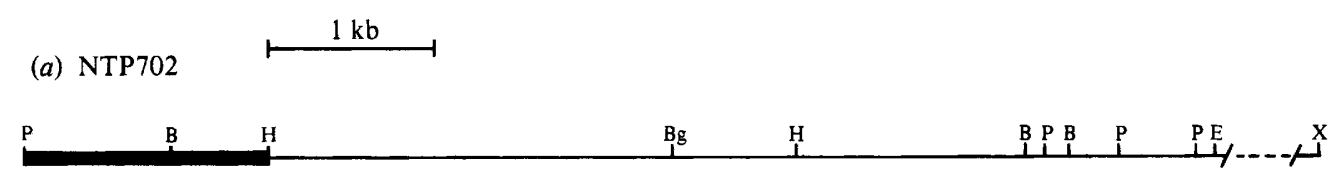

(b) NTP703

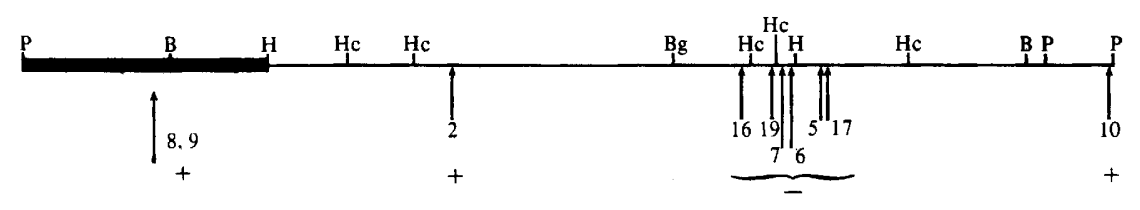

(c) NTP706

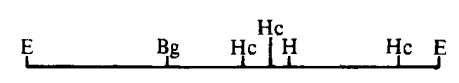

Fig. 1. Partial restriction maps of DNA cloned from the H19 VT phage. Sites for restriction enzymes: B, BamHI ; Bg, BglII ; E, EcoRI; H, HindIII; Hc, HincII; P, PstI ; X, XhoI. The map of NTP702 (a) includes a region of the vector plasmid pACYC177 (solid line) since this was retained in the formation of NTP703 (b). A length of NTP702 between the EcoRI and XhoI sites of the phage DNA has not been shown in full, and HincII sites are not included on this map. The map of NTP703 shows the sites of Tn 1000 insertion (arrowed) in the numbered plasmid mutants: +, no effect on VT production; -, loss of VT expression. The precise location of $\mathrm{Tn} 1000$ in vector sequences in mutants 8 and 9 was not determined. The EcoRI fragment present in NTP706 (c) was derived from a HaelII fragment as described in the text.

lying between the two cloned fragments had been deleted (compare Figs $1 a$ and $1 b$ ). A $5 \cdot 4 \mathrm{~kb}$ BamHI fragment of NTP702 (Fig. 1a) that is contained in NTP703 was cloned separately into pACYC184 to yield NTP704 (not shown); this plasmid coded for VT production and was used in some subsequent manipulations as indicated.

Further subcloning of VT sequences was carried out after the location of these had been suggested by mutagenesis and hybridization studies. A series of mutants of the plasmid NTP703 carrying Tn 1000 was generated as described in Methods. Of 19 strains tested for VT production 13 were $\mathrm{VT}^{+}$and 6 were $\mathrm{VT}^{-}$. With one exception these strains carried a plasmid approximately $6 \mathrm{~kb}$ larger than NTP703, indicating that insertion of Tn1000 into NTP703 had occurred.

DNA of all the NTP703::Tn 1000 mutants that no longer encoded VT was digested with HindIII or BamHI and the fragment patterns compared with that of NTP703 and four NTP703 : :Tn 1000 derivatives that still specified VT. From examination of these results in conjunction with the known restriction map of Tn1000 (Guyer, 1978), it was possible to map the insertion sites of the transposon on NTP703. These results are shown in Fig. $1(b)$. Of the four NTP703 : :Tn 1000 derivatives that still coded for VT production, two carried the transposon within vector DNA. In the other mutants, 2 and 10 , Tn 1000 was inserted in phage DNA sequences as shown in Fig. $1(b)$. The sites of Tn 1000 insertion in NTP703 that resulted in loss of the capacity to encode VT production were clustered around the HindIII site in the cloned phage DNA. In four $\mathrm{VT}^{-}$mutants, $6,7,16$ and $19, \mathrm{Tn} 1000$ insertion had occurred to the left of this HindIII site within a $3.2 \mathrm{~kb}$ HindIII fragment of NTP703, whereas in mutants 5 and 17 the transposon was located to the right of the HindIII site. The Tn 1000 insertion sites spanned a region of about $0.6 \mathrm{~kb}$.

Restriction mapping showed that this HindIII site in NTP703 and NTP704 was within a HincII fragment of $0.75 \mathrm{~kb}$ (Fig. $1 \mathrm{~b}$ ). The location of the Tn 1000 insertion was confirmed by examining HincII digests of the NTP703 mutants for the presence of this fragment. Control digests of the VT-encoding mutants 2 and 8 indicated that there were no similarly sized fragments arising from Tn 1000 . Of the mutants that had lost the ability to code for VT production, 5, 6, 7 and 17 did not have a $0.75 \mathrm{~kb}$ HincII fragment detectable visually on a gel or 
by Southern hybridization of the blotted gel to isolated radioactively-labelled $0.75 \mathrm{~kb}$ HincII fragment. The VT non-encoding mutants 16 and 19 retained this HincII fragment, confirming that these insertions were outside the fragment.

These results indicated that the $0.75 \mathrm{~kb}$. HincII fragment might be a useful probe for VT sequences (see next section). It formed part of a region associated with VT production although the extent of adjacent DNA also involved was not known. The HincII fragment was cloned into HincII-cleaved pACYC177 but, as expected from the mutagenesis results, an E. coli $\mathrm{K} 12$ strain carrying the hybrid plasmid (NTP705, not shown) did not produce VT.

Restriction mapping of NTP703 failed to indicate any fragments that could be readily cloned which were likely to contain all the VT sequences. A Bam HI-BglII fragment $(2 \cdot 2 \mathrm{~kb} ; \mathrm{Fig} .1$ b) that spanned the region of interest was used in hybridization with DNA of NTP704 digested with various restriction enzymes. A HaeIII fragment of $2.5 \mathrm{~kb}$ hybridized with the BamHI$B g / I I$ fragment and was cloned from a digest of NTP704 by ligation with EcoRI-treated DNA of pACYC184 that had been rendered flush-ended (Maniatis et al., 1982). Of 100 strains carrying recombinant plasmids, two were $\mathrm{VT}^{+}$and carried identical $6.6 \mathrm{~kb}$ plasmids (NTP706; Fig. $1 \mathrm{c}$ ). This is the smallest derivative obtained so far that codes for VT synthesis.

Further mapping experiments, together with the examination of plasmid-coded polypeptides in minicells are required to identify the regions coding for the subunits of the toxin. The Shigalike toxins of $E$. coli strains $\mathrm{H} 30$ and 933 have been reported to have the same A and B subunit structure as Shiga toxin (O'Brien et al., 1983a), although minor differences between Shiga toxin and the H30 Shiga-like toxin have been observed (O'Brien \& LaVeck, 1983).

\section{Application of VT probe sequences}

Specificity of the the probe. The specificity of the $0.75 \mathrm{~kb}$ HincII fragment as a probe for VT sequences was checked by hybridization to DNA of $\phi \mathrm{H} 19$, NTP703, NTP705, pBR322, pACYC177, phage $\lambda$ and NTP104, a plasmid of $63 \mathrm{~kb}$ determining heat-labile enterotoxin production. Restriction enzyme-generated fragments of phage or plasmid DNA were separated on agarose gels, transferred to nitrocellulose and hybridized with ${ }^{35} \mathrm{~S}$-labelled probe in the presence of $50 \%(\mathrm{v} / \mathrm{v})$ formamide (see Methods). There was strong hybridization to the homologous unlabelled HincII fragment in digests of NTP703 and NTP705 but no vector sequences of pACYC177 or pBR322 were detected. Hybridization of the $0.75 \mathrm{~kb}$ HincII fragment to HindIII-digested $\phi \mathrm{H} 19$ DNA detected homology with two HindIII fragments $(3.2 \mathrm{~kb}$ and $7.0 \mathrm{~kb})$, as would be predicted from the presence of a HindIII site in the probe sequence. There was no homology with fragments of control plasmid DNA of NTP104 or to phage $\lambda$. However, it appeared that some of the DNA cloned in NTP703 did have homology with $\lambda$ DNA since in preliminary experiments, in which the $5.4 \mathrm{~kb}$ BamHI fragment of NTP703 (Fig. $1 b$ ) was used as a probe, a $6.6 \mathrm{~kb}$ HindIII fragment of $\lambda$ hybridized.

Detection of $V T^{+}$E. coli. A panel of wild-type and $\mathrm{K} 12$ strains of $E$. coli was selected for colony hybridization tests with the radioactively labelled $0.75 \mathrm{~kb} H$ incII probe fragment. These experiments were done under conditions of high stringency. The wild-type $E$. coli comprised $\mathrm{VT}^{+}$and VT- O26. H11 strains including H19, E. coli of serotype O157. H7 or O157. $\mathrm{H}^{-}$which produced VT and were associated with cases of HUS or bloody diarrhoea in Britain, and VT $^{-}$ O157.H45 strains. The K12 strain used was AB1157; this was either plasmid-free or carried $\phi \mathrm{H} 19$ or NTP705. Results of the hybridization tests are listed in Table 1.

There was clear distinction between $\mathrm{VT}^{+}$and $\mathrm{VT}^{-} \mathrm{O} 26 . \mathrm{H} 11$ strains and between AB1157 and the same strain carrying the H19 VT phage or NTP705. Hybridization of this probe to $\mathrm{VT}^{+}$ O157 E. coli differentiated two classes. Strains E30228 and E30480 were detected as VT ${ }^{+}$by this probe whereas E30979 and E32511 were probe negative. This indicated that there are differences in the VT genes of the O157 strains. Strains of serogroup O157 that did not produce VT were negative in tests with the $0.75 \mathrm{~kb}$ HincII probe.

Strain E32511, which was probe negative in colony hybridization tests, was selected for further study since VT production in this strain was shown to be phage determined (Smith et al., 1984). DNA, prepared from E32511 VT phage ( $\phi \mathrm{E} 32511)$, was digested with Hincll. After transfer to nitrocellulose the fragments were tested for hybridization with the $0.75 \mathrm{~kb} \mathrm{H} 19$ 
Table 1. Testing of wild-type and K12 strains of E. coli by colony hybridization

$\begin{array}{lccc}\text { Strain no. } & \text { Serotype } & \text { VT production* } & \text { Hybridization }{ }^{\circ} \\ \text { H19 } & \text { O26.H11 } & + & + \\ \text { E9040 } & \text { O26.H11 } & + & + \\ \text { E9192 } & \text { O26.H11 } & - & - \\ \text { E7795 } & \text { O26.H11 } & - & - \\ \text { E30228 } & \text { O157.H7 } & + & + \\ \text { E30480 } & \text { O157.H7 } & + & + \\ \text { E30979 } & \text { O157.H7 } & + & - \\ \text { E32511 } & \text { O157.H- } & + & - \\ \text { E9818 } & \text { O157.H45 } & - & - \\ \text { E10376 } & \text { O157.H45 } & - & - \\ \text { K12 (H19 VT phage) } & & + & + \\ \text { K12 (NTP705) } & & - & + \\ \text { K12 } & & - & -\end{array}$

* Assayed against Vero cells as described in Methods.

† With a $0.75 \mathrm{~kb} \mathrm{H} 19$ HincII probe.

probe. Under conditions of high stringency no homology was detected. However, when lower stringency was used weak binding was observed with a $2 \mathrm{~kb}$ HincII fragment but no homology was detected at a position on the blot corresponding to $0.75 \mathrm{~kb}$.

These results indicate that there is heterogeneity in the VT sequences of the 0157 strains and this may reflect differences in the VTs encoded by these genes. These observations can be compared to the studies with the STIa (or $\mathrm{ST}_{\mathrm{A} 1}$ ) and STIb (or $\mathrm{ST}_{\mathrm{A} 2}$ ) genes (De Wilde et al., 1981; Moseley et al., 1983). The two ST genes have approximately $70 \%$ homology but do not hybridize under stringent conditions. However, the two ST toxins have a close structural and immunological similarity.

\section{Cloning of VT sequences from the E32511 VT phage}

DNA of $\phi E 32511$ was digested with EcoRI and fragments were ligated with similarly cleaved pACYC184. Of 50 transformants tested for VT production four were $\mathrm{VT}^{+}$. Three of these four strains carried recombinant plasmids with a molecular size of $8.6 \mathrm{~kb}$. Digestion with EcoRI showed that the $8.6 \mathrm{~kb}$ plasmids carried inserts of $4.7 \mathrm{~kb}$; one of these plasmids was designated NTP707. Hybridization of HincII-digested NTP707 with the $0.75 \mathrm{~kb} \mathrm{H19}$ probe showed that a $2 \mathrm{~kb}$ HincII fragment within the $4.7 \mathrm{~kb}$ EcoRI fragment showed weak homology under conditions of low stringency. This confirmed the results obtained with the total DNA of $\phi \mathrm{E} 32511$.

The $2 \mathrm{~kb}$ HincII fragment of NTP707 and the $0.75 \mathrm{~kb}$ HincII probe derived from NTP705 are being used for hybridization to test strains of $E$. coli and Shigella and also to detect $\mathrm{VT}^{+}$ organisms in faecal specimens isolated from cases of HUS. Details of these experiments will be reported separately. The use of hybridization for testing strains present in faecal samples is particularly useful in cases where the proportion of $\mathrm{VT}^{+}$organisms is low (Karmali et al., 1983b). This approach, together with toxin testing and serotyping, should provide valuable information on the role of $E$. coli producing Vero toxins in the pathogenesis of HUS and bloody diarrhoea.

\section{REFERENCES}

BachmanN, B. J. (1972). Pedigrees of some mutant strains of Escherichia coli K12. Bacteriological Reviews 36, 525-557.

Birnboim, H. C. \& Doly, J. (1979). A rapid alkaline extraction procedure for screening recombinant plasmid DNA. Nucleic Acids Research 7, 1513-1523.

Dagert, M. \& Ehrlich, S. D. (1979). Prolonged incubation in calcium chloride improves the competence of Escherichia coli cells. Gene 6, 23-28.
DE WiLde, M., YAEbaERT, M. \& HARFORD, N. (1981). DNA sequence of the $\mathrm{ST}_{\mathrm{A} 2}$ enterotoxin gene from an Escherichia coli strain of human origin. In Molecular Biology, Pathogenicity and Ecology of Bacterial Plasmids, p. 596. Edited by S. B. Levy, R. C. Clowes \& E. L. Koenig. New York: Plenum.

GULLEY, P. R. (1984). Haemolytic-uraemic syndrome: epidemiology and report of an outbreak. Journal of the Royal Society of Health 104, 214-217. 
GuYer, M. S. (1978). The $\gamma \delta$ sequence of $F$ is an insertion sequence. Journal of Molecular Biology 126, 347-365.

Humphreys, G. O., Willshaw, G. A. \& Anderson, E. S. (1975). A simple method for the preparation of large quantities of pure plasmid DNA. Biochimica et biophysica acta 383, 457-463.

Johnson, W. M., Lior, H. \& Bezanson, G. S. (1983). Cytotoxic Escherichia coli $\mathrm{O} 157: \mathrm{H} 7$ associated with haemorrhagic colitis in Canada. Lancet i, 76.

JoRgensen, R. A., RothsteIn, S. J. \& REZnikoff, W. S. (1979). A restriction enzyme cleavage map of $\operatorname{Tn} 5$ and location of a region encoding neomycin resistance. Molecular and General Genetics 177, 65-72.

Karmali, M. A., Petric, M., Lim, C., Fleming, P. C. \& SteEle, B. T. (1983a). Escherichia coli cytotoxin, haemolytic-uraemic syndrome, and haemorrhagic colitis. Lancet ii, 1299-1300.

Karmali, M. A., Steele, B. T., Petric, M. \& Lim, C. $(1983 b)$. Sporadic cases of haemolytic uraemic syndrome associated with faecal cytotoxin and cytotoxin-producing Escherichia coli in stools. Lancet i, 619-620.

KashiwaZaKi, M., OgaWa, T., Isayama, Y., AKaIKe, Y., TAMURA, K. \& SAKAZAKI, R. (1980). Detection of Vero cytotoxic strains of Escherichia coli isolated from diseased animals. National Institute of Animal Health Quarterly (Japan) 20, 116-117.

Kashiwazaki, M., OgaWa, T., Nakamura, K., ISAYAMA, T., TAMURA, K. \& SAKAZAKI, R. (1981). Vero cytotoxin produced by Escherichia coli strains of animal origin. National Institute of Animal Health Quarterly (Japan) 21, 69-72.

Konowalchuk, J., Speirs, J. I. \& Stavric, S. (1977). Vero response to a cytotoxin of Escherichia coli. Infection and Immunity 18, 775-779.

Maniatis, T., Fritsch, E. F. \& SambrooK, J. (1982). Molecular Cloning: a Laboratory Manual. Cold Spring Harbor, NY: Cold Spring Harbor Laboratory.

Moseley, S. L., Hardy, J. W., HuQ, M. I., EcheverRIA, P. \& FALKOW, S. (1983). Isolation and nucleotide sequence determination of a gene encoding a heat-stable enterotoxin of Escherichia coli. Infection and Immunity 39, 1167-1174.

O'Brien, A. D. \& LaVeck, G. D. (1983). Purification and characterization of a Shigella dysenteriae 1-like toxin produced by Escherichia coli. Infection and Immunity 40, 675-683.

O'Brien, A. D., LaVeck, G. D., Thompson, M. R. \& Formal, S. B. (1982). Production of Shigella dysenteriae type 1-like cytotoxin by Escherichia coli. Journal of Infectious Diseases 146, 763-769.

O'Brien, A. D., Lively, T. A., Chang, T. W. \& GorbaCH, S. L. (1983a). Purification of Shigella dysenteriae 1 (Shiga)-like toxin from Escherichia coli
O157:H7 strain associated with haemorrhagic colitis. Lancet ii, 573.

O'Brien, A. D., Lively, T. A., Chen, M. E., Rothman, S. W. \& Formal, S. B. (1983b). Escherichia coli $\mathrm{O} 157$ : $\mathrm{H} 7$ strains associated with haemorrhagic colitis in the United States produce a Shigella dysenteriae 1 (Shiga)-like cytotoxin. Lancet i, 702.

O'Brien, A. D., Newland, J. W., Miller, S. F., Holmes, R. K., Williams SMith, H. \& Formal, S. B. (1984). Shiga-like toxin-converting phages from Escherichia coli strains that cause hemorrhagic colitis or infantile diarrhea. Science 226, 694-696.

Peacock, A. D. \& Dingman, C. W. (1968). Molecular weight extraction and separation of ribonucleic acid by electrophoresis in agarose-acrylamide composite gels. Biochemistry 7, 668-674.

Scotland, S. M., Day, N. P. \& Rowe, B. (1980a). Production of a cytotoxin affecting Vero cells by strains of Escherichia coli belonging to traditional enteropathogenic serogroups. FEMS Microbiology Letters 7, 15-17.

Scotland, S. M., Day, N. P., Willshaw, G. A. \& Rowe, B. $(1980 b)$. Cytotoxic enteropathogenic Escherichia coli. Lancet i, 90.

Scotland, S. M., Smith, H. R., Willshaw, G. A. \& Rowe, B. (1983). Vero cytotoxin production in strain of Escherichia coli is determined by genes carried on bacteriophage. Lancet ii, 216.

Smith, H. R., Day, N. P., Scotland, S. M., Gross, R. J. \& Rowe, B. (1984). Phage-determined production of Vero cytotoxin in strains of Escherichia coli serogroup O157. Lancet i, 1242-1243.

SOUTHERN, E. M. (1975). Detection of specific sequences among DNA fragments separated by agarose gel electrophoresis. Journal of Molecular Biology 98, 503-517.

Southern, E. M. (1979). Gel electrophoresis of restriction fragments. Methods in Enzymology 68, 152-176.

Wade, W. G., Thом, B. T. \& Evans, N. (1979). Cytotoxic enteropathogenic Escherichia coli. Lancet ii, $1235-1236$.

Williams Smith, H. \& Linggood, M. A. (1971). The transmissible nature of enterotoxin production in a human enteropathogenic strain of Escherichia coli. Journal of Medical Microbiology 4, 301-305.

Williams Smith, H., Green, P. \& Parsell, Z. (1983). Vero cell toxins in Escherichia coli and related bacteria: transfer by phage and conjugation and toxic action in laboratory animals, chickens and pigs. Journal of General Microbiology 129, 3121-3137.

Willshaw, G. A., Smith, H. R. \& ANDERSon, E. S. (1979). Application of agarose gel electrophoresis to the characterization of plasmid DNA in drugresistant enterobacteria. Journal of General Microbiology 114, 15-25. 